Wildenthal, Lora. Review of Feminism and Motherhood in Western Europe, 1890-1970: The Maternal Dilemma, by Ann Taylor Allen. Central European History 40 (2007): 738-740. doi: 10.1017/S0008938907001173.

\title{
Feminism and Motherhood in Western Europe, 1890-1970: The Maternal Dilemma. By Ann Taylor Allen. New York: Palgrave Macmillan. 2005. Pp. xii+354. \$85.00. ISBN 1-4039-6236-7.
}

\author{
Lora Wildenthal, Rice University
}

This is a masterful synthesis of the history of one of the most important themes in feminist thought and activism. Ann Taylor Allen's earlier work on feminism and motherhood in Germany no doubt helped her take on this daunting task, but the present volume is a fully comparative European survey. Focusing on a set of clearly articulated questions, Allen takes the reader through issues, contexts, and disputes in Britain, France, Germany, and the Netherlands, with some coverage of Sweden, Norway, and Denmark, and (more rarely) Spain, Italy, Portugal, Switzerland, and Ireland. The unevenness reflects the varying prominence of feminist activism in these countries during the time period under investigation. While plenty of secondary literature is cited, and sometimes explicitly discussed, the text derives its liveliness from its closeness to primary sources from all the major countries. It is a well-written and highly readable text. Only its price and length speak against its wide use in undergraduate classrooms. Certainly it should be the first book students and scholars turn to outside the classroom for orienting themselves on this topic.

What is the "maternal dilemma"? As Allen points out, there must first be a choice before one can speak of a dilemma. Only since the turn of the twentieth century, Allen argues, could European women think of motherhood as a choice, and it is from that time that we can date feminist explorations of the problem of whether "it is possible to be both a mother and an autonomous individual" (p. 1). How to be both is the "maternal dilemma."

The book traces a large-scale shift from feminists' embrace ca. 1900 of motherhood as the prime mode of women's social achievement to the questioning ca. 1970 of the value of motherhood. While the former argued that motherhood's importance required legal and social changes to improve women's status, the latter argued that the very condition of motherhood precluded or seriously hampered women's self-realization. Allen attributes large-scale changes such as this to 
supranational patterns of falling birth rates, increased financial and emotional investment in children, and new ideas regarding work and marriage, as well as to debates and conditions within each country.

Of its nine chapters, four concern the pre-World War I era, laying out the rich array of debates related to motherhood to be found in the "first wave" feminist movements of Europe. Chapter one is an account of the late-nineteenth-century debate on prehistorical matriarchy and the historical contingency of patriarchy. Chapter two takes up arguments in favor of empowering women as they carried out maternal tasks by increasing women's legal rights, whether as married or [End Page 738] unmarried mothers. The same period saw the emergence of the idea of children's rights - both approaches serving to limit paternal power. Chapter three concerns the question of mothers' paid industrial work (key to women's autonomy) and of treating motherhood as paid work, to be endowed by the state (which tended to reduce women's autonomy, by authorizing interventions into family privacy). Chapter four deals with prewar debates on eugenics, sex education, and birth control. Here Allen concludes, "Contrary to the picture of eugenics given by many historians, who emphasize its coercive aspects, most feminist legislative proposals avoided compulsion and emphasized voluntarism and individual responsibility" ( $p$. 106). All of these chapters show feminists seeking to relieve the pressure of the "maternal dilemma" by seeking to increase women's autonomy as mothers.

While Allen avoids material on war and dictatorships, in which meaningful feminist activism was not possible - this being a history of feminisms, not of women - she does spend one chapter on the First World War. Here she takes up debates on mothers' roles in wartime as workers or dependents, the role of the state in promoting or otherwise manipulating birth rates, the place of "illegitimate" children, and maternalism as a component of pacifist feminism.

Three chapters on the interwar era follow: on paid employment, eugenics, and the individual's "right to be happy." This latter development signaled a major shift in cultural expectations of family life, from taking children for granted to seeing them as a chosen source of self-fulfillment. With more choice came the intensification of the "maternal dilemma," as the chosen burden was not to be put aside lightly.

The final chapter takes up post-World War II feminisms in Europe, especially the ever more prominent issue of mothers in the paid labor force. Allen points out the new prominence of the argument that mothers had the right to work for personal satisfaction (now added to the older argument of economic need). She traces social science discussions that rendered motherhood a temporary, rather than a lifetime, obligation and that affirmed institutionalized child care. These of course supported the idea of the working mother. Allen also takes up legal changes in women's parental rights, including as unmarried mothers. It is only in the post-World War II era that children of unmarried mothers gain equal rights with those of parents married to each other. Finally, she takes up the 1970s "rebellion against maternity" (p. 209), especially via Simone de Beauvoir, who argued that maternity and autonomy were completely incompatible (p. 228). Allen points out that it was difficult for such arguments to avoid, by default, accepting male life patterns as the norm. 
While some scholars focus on the many conflicts within feminism, Allen has always been an advocate of the "big tent," and here she takes Karen Offen's classic definition of feminism as her point of departure. In all her work, she has sought to bring themes considered traditionally feminine, such as the [End Page 739] family, kindergarten theory, and nursing into view in feminist scholarship, and to counter their perception as necessarily conservative. Her big picture certainly lays to rest the illusion of too many Europeans and Americans today who, unacquainted with the past or present of feminism, believe that feminists are uncaring about motherhood. Those well versed in the history of feminism will still find much that is new to them. Allen offers an expert and judicious survey focused around a dilemma that is as current as ever. As she says, "the greater her freedom of choice and the broader her options, the more complex is the individual's decision for or against childbearing" (p. 237). This increasing freedom of choice coexists with perduring injustices against women to create the complex situation surrounding motherhood in all its forms today. 